\title{
Papers
}

\section{Relation of Bcl-2 expression to androgen receptor, p21WAF1/CIP1, and cyclin D1 status in prostate cancer}

\author{
Z Kolář, P G Murray, K Scott, A Harrison, B Vojtěšek, J Dušek
}

\begin{abstract}
Background-There is currently no effective treatment for recurrent hormone refractory carcinomas of the prostate gland. An understanding of the underlying mechanisms responsible for the progression of these lesions is likely to be important for the development of new therapeutic approaches. Recently, it has been suggested that the transition to a hormone independent state is accompanied by increased proliferation and bcl-2 gene expression, as well as by a decreased apoptotic state.

Aim-To investigate the possible role of Bcl-2 and other cell cycle regulating proteins in the development of prostatic tumours.

Methods-Immunohistochemistry was used to study the relation between the expression of $\mathrm{Bcl}-2$ and the androgen receptor, as well as p21WAF1/CIP1 (p21), and cyclin D1 status, in a series of 89 prostate cancer samples taken before androgen withdrawal treatment.
\end{abstract}

Centre of Molecular Biology and Medicine, Palacký University, CZ-77515 Olomouc, Czech

Z Kolár̆

Institute of Pathology, Palacký University J Dušek

School of Health Sciences, University of Wolverhampton WV1 1DJ, UK

P G Murray

Department of Histopathology, New Cross Hospital, Wolverhampton

WV10 0QP, UK

A Harrison

K Scott

Masaryk Memorial Cancer Institute, Brno, Czech Republic B Vojtěšek

Correspondence to: Professor Kolár email: kolarz@risc.upol.cz

Accepted for publication 21 September 1999 differentiation, and apoptosis. The assessment of these genetic abnormalities, coupled with the precise measurement of proliferative potential, can provide important information about prognosis and response to treatment.

The prostate gland is dependent on the presence of circulating androgens to maintain its normal structure and function. Likewise, $70-80 \%$ of prostatic neoplasms are androgen sensitive tumours that undergo regression after chemical or surgical androgen ablation. ${ }^{1}$ The cell clones that are selected during androgen withdrawal treatment give rise to androgen independent prostate carcinomas. Such recurrent tumours are clinically more aggressive and the prognosis after relapse is poor. ${ }^{2}$ To date, no effective treatment has been developed for these hormone refractory carcinomas.

Recently, it has been postulated that the transition to a hormone independent state is accompanied by increased proliferation and $\mathrm{Bcl}-2$ expression, as well as by a decreased rate of apoptosis. ${ }^{3}$ Apoptosis is an active ATP dependent process that, in the prostate, can be mediated via an increase in the intracellular calcium concentration. ${ }^{4}$ The bcl-2 gene encodes a 26 $\mathrm{kDa}$ protein $\mathrm{Bcl}-2$, which prevents apoptosis when overexpressed in prostate cells. ${ }^{5}$ In previous studies, Bcl-2 expression was found to be more frequent in higher grade tumours and to predict disease progression. ${ }^{6}$ Therefore, the involvement of Bcl-2 in the development of hormone refractory prostatic tumours seems probable. ${ }^{7}$ In addition, the cyclin dependent kinase inhibitor, p21WAF1/CIP1 (p21), and cyclin D1 might be actively involved in these processes. Therefore, the aim of this study was to investigate the expression of $\mathrm{Bcl}-2$ in relation to these various cell cycle regulating proteins.

\section{Materials and methods}

PATIENTS AND SPECIMENS

The expression of Bcl-2, the androgen receptor, $\mathrm{p} 21$, and cyclin D1 was analysed by immunohistochemistry in 89 paraffin wax embedded prostatic cancer samples (graded between 3 and 9 according to the Gleason system) before androgen withdrawal treatment. The samples were obtained from the Institute of Pathology, Palacký University, Olomouc and from the department of histopathology, New Cross Hospital, Wolverhampton. 

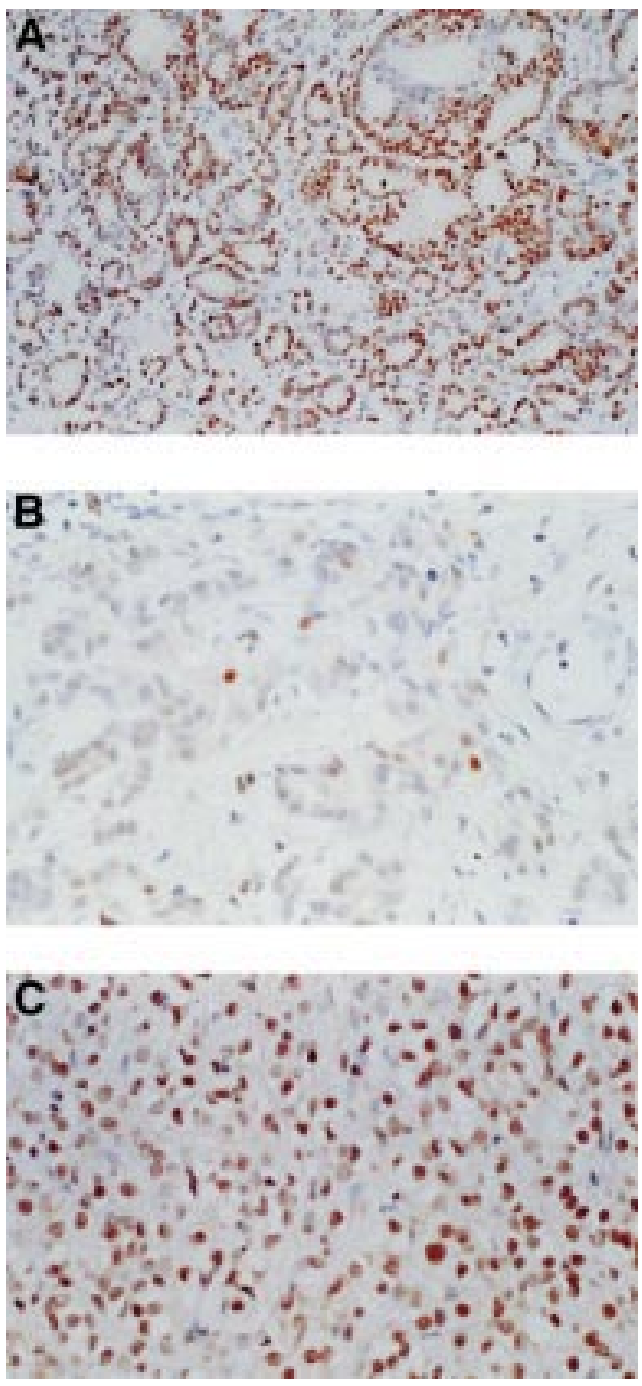

Figure 1 (A) Typical nuclear staining for the androgen receptor in prostatic cancer. (B) Nuclear staining for $p 21$ in $\mathrm{Bcl}-2$ positive prostatic cancer. (C) Intense nuclear staining for cyclin D1 in androgen receptor positive prostatic cancer.

MEASUREMENT

The numbers of positive cells were evaluated semiquantitatively by two independent investigators and by computer image analysis (LUCIA M; Laboratory Imaging, Prague, Czech Republic) in identical areas of parallel sections, and converted to a $0-3$ scale $(0$, no positive cells; 1 , up to $33.3 \%$ positive cells; 2 , between $33.3 \%$ and $66.6 \%$ positive cells; 3 , between $66.6 \%$ and $100 \%$ positive cells). Any disagreement between evaluators was checked and measurements were repeated.

IMMUNOHISTOCHEMISTRY

Primary antibodies to the androgen receptor (clone F39.4.1; Biogenex, San Ramon, Californa, USA), Bcl-2 (clone 124; Dako, Copenhagen, Denmark), p21 (clone WA1; MMCI, Brno, Czech Republic), and cyclin D1 (clone CD2.1; MMCI) were used in standard immunohistochemical methods. A biotinylated secondary antibody and streptavidin/biotin complexed with horseradish peroxidase (HRP) (streptABComplex/HRP duet kit; Dako) were also used and HRP activity was developed by means of 3,3'-diaminobenzidine.
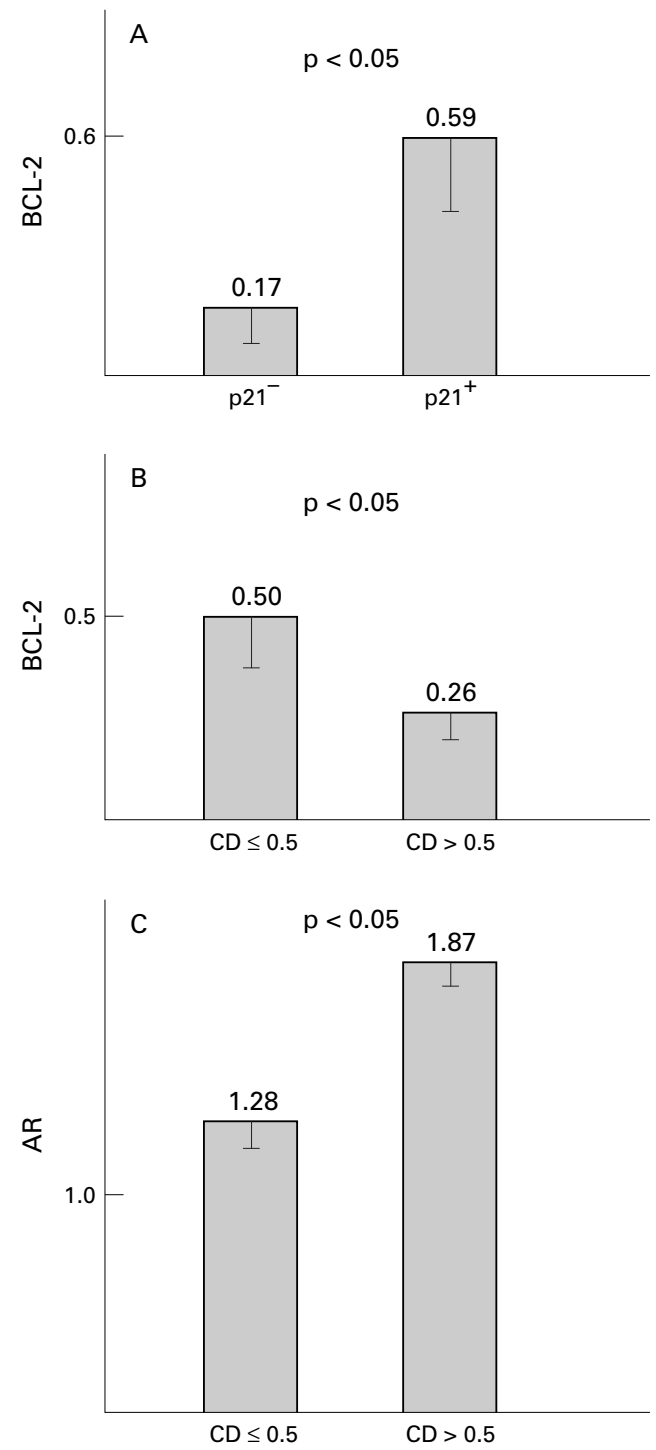

Figure 2 (A) Relation between Bcl-2 and $p 21$ expression in prostatic cancer. (B) Relation between Bcl-2 and cyclin D1 (CD) expression in prostatic cancer. (C) Relation between androgen receptor $(A R)$ and cyclin D1 expression in prostatic cancer.

STATISTICS

Statistical analysis was performed using a $\chi^{2}$ test for independence and homogeneity of variance (department of biometry, Palacký University, Olomouc, Czech Republic).

\section{Results}

Figure 1A-C shows representative immunohistochemical results. Androgen receptor positive prostate cancers (more than $10 \%$ positive cells) occurred in both low (Gleason 3-5) as well as high (Gleason 8,9) grade carcinomas. In medium grade (Gleason 6,7) carcinomas expression of the androgen receptor was generally lower. These results were not significant because of the low number of high grade carcinomas. Analysis of the relation between Bcl-2 and androgen receptor expression revealed that Bcl-2 expression was significantly higher in androgen receptor negative prostatic cancers than in those samples with low/medium androgen receptor scores (score, 0.5-2.0; $\mathrm{p}<0.05$ ). 
However, in samples with the highest androgen receptor positivity, a slightly higher amount of $\mathrm{Bcl}-2$ expression was noted, which was not significantly different from that found in androgen receptor negative samples. Bcl-2 expression was significantly higher in $\mathrm{p} 21$ positive tumours compared with those tumours in which p21 expression was absent $(\mathrm{p}<0.05)$ (fig 2A). There was also a significant inverse relation $(p<0.05)$ between expression of $\mathrm{Bcl}-2$ and cyclin D1 (fig 2B) and a significant positive relation $(p<0.05)$ between expression of the androgen receptor and cyclin D1 (fig 2C). No other significant associations were seen, but a trend towards increasing p21 expression in cases with high concentrations of cyclin D1 was noted (data not shown).

\section{Discussion}

Recent reports suggest that combined endocrine treatment induces tumour regression by greatly reducing proliferation. ${ }^{8-10}$ However, other studies have also identified programmed cell death as the molecular mechanism underlying regression of androgen dependent human prostatic cancer after androgen ablation. ${ }^{8-14}$

Many recent papers have examined the role of $\mathrm{p} 21$ in the control of cell proliferation. ${ }^{15}$ This nuclear protein is an inhibitor of several cyclin dependent kinases and a component of the quaternary complex (including cyclin D1, specific cyclin dependent kinase, and proliferating cell nuclear antigen). ${ }^{16}$ The expression of $\mathrm{p} 21$ is variable among different human tissues, ${ }^{17}$ and has been implicated in the mechanisms of cell cycle arrest that allow DNA repair in response to wild-type, but not to mutant, p53. ${ }^{18-20}$ However, some recent findings demonstrate that p21 might also be induced in a p53 independent manner, for example by transforming growth factor $\beta .{ }^{15} \mathrm{p} 21$ has also been postulated as an inducer of cyclin D1 in vitro and a significant association has been shown between p21 and cyclin D1 expression in breast cancer. $^{21}$

Given the association between high concentrations of cyclin D1 and the increased proliferative activity found in some tumours, it was expected that overexpression of this protein would be associated with poor prognosis. Kallakury and co-workers ${ }^{22}$ analysed the expression of cyclin D1 in prostatic carcinoma and found that it was expressed in a minority of cases, where it was associated with a high Gleason grade. Detailed studies, however, did not show any significant association with recurrence or overall survival. ${ }^{23}$ On the other hand, overexpression of cyclin D1 was found more commonly in oestrogen receptor positive breast cancer, suggesting that cyclin D1 expression could be considered a marker of good prognosis. ${ }^{21}$

In untreated prostatic carcinoma, we found that there is a direct relation between androgen receptor and cyclin D1 expression, which is in accordance with the findings in breast cancer. This could be explained by steroid upregulation of cyclin D1. We have also found an association between increasing androgen receptor score and lower concentrations of the antiapoptotic protein $\mathrm{Bcl}-2$. This supports the concept that Bcl-2 expression is developing in hormone independent prostate cancer. The finding of higher Bcl-2 concentrations in a few samples with the highest androgen receptor scores is in agreement with the theory that high grade prostatic cancers often synthesise high concentrations of mutant androgen receptor. ${ }^{24} 25$

One of the most interesting results was that increasing $\mathrm{Bcl}-2$ expression was correlated with increasing concentrations of $\mathrm{p} 21$ but decreasing concentrations of cyclin D1. We suggest that this could be the consequence of a specific regulatory pathway in which Bcl-2, probably in accordance with androgens, upregulates the expression of $\mathrm{p} 21$, whereas the expression of cyclin D1 is suppressed. However, the relation between hormone responsiveness and expression of these various regulatory genes in prostate cancer remains unclear, although Chen et al have shown that p21 expression as well as expression of another cyclin dependent kinase inhibitor, p27, can be regulated, either directly or indirectly, by androgens. ${ }^{26}$

In conclusion, our results show that the expression of p21 and cyclin D1 in prostatic cancer might be modulated by $\mathrm{Bcl}-2$ and androgens and that it may well be related to the progression of prostate cancer.

The work was supported in part by grants MSMT J14/98 151100001, IGA MZ CR 4020-3, and 4783-3.

1 Deneshgari F, Crawford ED. Endocrine therapy of advanced carcinoma of the prostate. Cancer 1993;71:1089-97.

2 Stearns ME, McGarvey T. Prostate cancer: therapeutic, diagnostic, and basic studies. Lab Invest 1992;67:540-52.

3 Dorkin TJ, Neal DE. Basic science aspects of prostate cancer. Semin Cancer Biol 1997;8:21-7.

4 Kyprianou N, English HF, Isaacs JT. Activation of $\mathrm{Ca} 2+/ \mathrm{Mg} 2+$ dependent endonucleases as an early event in castration-induced prostatic cell death. Prostate 1989;13: 103-18.

5 Hochenberry DM, Nunez G, Milliman C. Bcl-2 is an inner mitochondrial membrane protein that blocks programmed cell death. Nature 1990;348:334-6.

6 Bubendorf L, Sauter G, Moch H, et al. Prognostic significance of $\mathrm{Bcl}-2$ in clinically localized prostate cancer. Am f Pathol 1996;148:1557-65.

7 Raffo AJ, Perlman H, Chen MW, et al. Overexpression of Raffo AJ, Perlman H, Chen MW, et al. Overexpression of
bcl-2 protects prostate cancer cells from apoptosis in vitro and confers resistance to androgen depletion in vivo. Cancer Res 1995;55:4438-45.

8 Magi-Galluzzi C, Montironi R, Giannulis G, et al. Prostatic invasive adenocarcinoma: effect of combination endocrine therapy (LHRH agonist and flutamide) on the expression and location of proliferating cell nuclear antigen (PCNA). Pathol Res Pract 1993;189:1154-60.

9 Montironi R, Magi-Galluzzi C, Diamanti L, et al. Prostatic intra-epithelial neoplasia: expression and location of proliferating cell nuclear antigen (PCNA) in epithelial, endothelial and stromal nuclei. Virchows Arch 1993;422:185-92.

10 Montironi R, Magi-Galluzzi C, Fabris G. Apoptotic bodies in prostatic intraepithelial neoplasia and prostatic adenocarcinoma following total androgen ablation. Pathol Res Pract 1995;191:873-80.

11 Armas OA, Melamed A, Aprikian A, et al. Effect of preoperative androgen deprivation therapy in prostatic carpreoperative androgen deprivation

12 Colombel M, Symmans F, Gil S, et al. Detection of the apoptosis-suppressing oncoprotein bcl-2 in hormonerefractory human prostate cancers. Am F Pathol 1993;143: $390-400$

13 Kyprianou N, Bains AK, Jacobs SC. Induction of apoptosis in androgen-independent human prostate cancer cells undergoing thymineless death. Prostate 1994;25:66-75.

14 Montironi R, Magi-Galluzzi C, Muzzonigro G, et al. Effects of combination endocrine treatment on normal prostate, prostatic intraepithelial neoplasia, and prostatic adenocarcinoma. F Clin Pathol 1994;47:906-13.

15 Cox LS. Multiple pathways control cell growth and transformation: overlapping and independent activities of p53 and p21Cip1/WAF1/Sdi1. I Pathol 1997;183:134-40. p53 and p21 Cip1/WAF1/Sdil. F Pathol 1997;183:134-40.
16 Xiong Y, Zhang H, Beach D. D type cyclins associate with multiple protein kinases and the DNA replication and repair factor PCNA. Cell 1992;71:505-14. 
17 Fredersdorf S, Milne AW, Hall PA, et al. Characterization of a panel of novel anti-p21Waf1/Cip1 monoclonal antibodies and immunel ami-p21 in normal human tissues. Am F Pathol 1996;148:825-35.

$18 \mathrm{Li} \mathrm{R}$, Waga S, Hannon GJ, et al. Differential effects by the p21 CDK inhibitor on PCNA-dependent DNA replication and repair. Nature 1994;371:534-7.

19 Waga S, Hannon GJ, Beach D, et al. The p21 inhibitor of cyclin-dependent kinases controls DNA replication by interaction with PCNA. Nature 1994;369:574-8.

20 El Deiry WS, Tokino T, Velculeccu VE, et al. WAF1, a potential mediator of p53 tumor suppression. Cell 1993;75: $817-25$.

21 Rey MJ, Fernandez PL, Jares P, et al. p21WAF1/Cip1 is associated with cyclin D1CCND1 expression and tubular differentiation but is independent of $\mathrm{p} 53$ overexpression in human breast carcinoma. F Pathol 1998;184:265-71.
22 Kallakury BVS, Sheehan CE, Ambros RA, et al. The prognostic significance of $\mathrm{p} 34 \mathrm{cdc} 2$ and cyclin D1 protein expression.

23 Barnes DM. Cyclin D1 in mammary carcinoma. 7 Pathol 1997;181:267-69.

24 Chodak GW, Kranc DM, Puy LA, et al. Nuclear localization of androgen receptor in heterogeneous samples of normal, hyperplastic and neoplastic human prostate. $f$ Urol 1992;147:798-803.

25 Habib FK, Odoma S, Busuttil A, et al. Androgen receptors in cancer of the prostate. Correlation with the stage and grade of the tumor. Cancer Res 1986;47:2351-6.

26 Chen Y, Robles AI, Martinez LA, et al. Expression of G1 cyclins, cyclin-dependent kinases, and cyclin-dependent kinase inhibitors in androgen-induced prostate proliferation in castrated rats. Cell Growth Differ 1996;7:1571-8.

\section{Fournal of Clinical Pathology - http://www.molpath.com}

Visitors to the world wide web can now access the fournal of Clinical Pathology either through the BMJ Publishing Group's home page (http://www.bmjpg.com) or directly by using its individual URL (http://www.molpath.com). There they will find the following:

- Current contents list for the journal

- Contents lists of previous issues

- Members of the editorial board

- Information for subscribers

- Instructions for authors

- Details of reprint services.

A hotlink gives access to:

- BMJ Publishing Group home page

- British Medical Association web site

- Online books catalogue

- BMJ Publishing Group books.

The web site is at a preliminary stage and there are plans to develop it into a more sophisticated site. Suggestions from visitors about features they would like to see are welcomed. They can be left via the opening page of the BMJ Publishing Group site or, alternatively, via the journal page, through "about this site". 